\title{
TERRITORIAL CAPITAL AND REGIONAL DEVELOPMENT: AN ANALYSIS OF TWO HUNGARIAN DISTRICTS
}

\author{
Gergely KABAI ${ }^{\mathrm{a}}$, Miklós OLÁH ${ }^{\mathrm{b}}$, Pál SZABÓ ${ }^{\mathrm{c}, *}$ \\ a) Pannon.Elemzö Iroda, Gyulaj, Hungary, ${ }^{b}$ Lake Balaton Development \\ Coordination Agency, Siófok, Hungary, ${ }^{c}$ Eötvös Loránd University, Department \\ of Regional Science, Budapest, Hungary
}

Please cite this article as:

Kabai, G., Oláh, M., Szabó, P., 2017. Territorial capital and regional development: An analysis of two Hungarian districts. Review of Economic Studies and Research Virgil Madgearu, 10(2), pp.81-93.

doi: 10.24193/RVM.2017.10.11.
Article History:

Received: 30 July 2017 Accepted: 13 September 2017

Abstract: Lake Balaton is the second most popular tourist destination in Hungary, after the capital. This resort area has strong territorial capital, but there are regional differences in economic performance. This study examines the social and economic differences between two small districts (Keszthely and Fonyód) of this recreation area. The research is based on territorial statistical data and a questionnaire survey taken by the respective mayors and local entrepreneurs. The results of data analysis show Keszthely is a more developed and Fonyód is a less developed district in several respects, and the results of the survey reveal the social background of this as there are differences in three measurement dimensions of social capital (relationships, trust, territorial attachment).

Key words: territorial capital; social capital; regional development; Hungary; Lake Balaton

JEL Classification: $L 83$; $O 18$; R11

(C) 2017 Alma Mater Publishing House. All rights reserved.

* Corresponding author. E-mail address: szabopalpeter@t-online.hu. 
Kabai, Oláh, Szabó, Territorial Capital and Regional Development...

\section{References}

1. Buday-Sántha, A., 2007. Development Issues of the Balaton Region, Budapest: Saldo.

2. Camagni, R., 2008. Regional competitiveness: towards a concept of territorial capital. In Capello, R., Camagni, R., Chizzolini, B. and Fratesi, U. (eds.), 2008. Modelling regional scenarios for the enlarged Europe. European competitiveness and global strategies, Berlin: Springer, pp.33-46.

3. Camagni, R., 2009. Territorial capital and regional development. In Capello, R. and Nijkamp, P. (eds.), Handbook of regional growth and development theories. Cheltenham-Northampton: Edward Elgar, pp.118-132.

4. Dudwick, N., Kuehnast, K., Jones, V.N. and Woolcock, M., 2006. Analyzing social capital in context, a guide to using qualitative methods and data, World Bank Institute: Washington DC, [Online], Available at: http://siteresources.worldbank. org/WBI/Resources/Analyzing_Social_Capital_in_ContextFINAL.pdf. [Accessed 18 November 2016].

5. European Commission (EC), 2005. The territorial state and perspectives of the European Union. Towards a stronger European territorial cohesion in the light of the Lisbon and Gothenburg ambitions. First Draft. Brussels: European Commission.

6. Eurofund, 2012. European Quality of Life Surveys, [online]. Available at: http:// www.eurofound.europa.eu/surveys/european-quality-of-life-surveys-eqls/ european-quality-of-life-survey-2012. [Accessed 16 November 2016].

7. ESS, 2014. European Social Survey, [online], Available at: http://www. europeansocialsurvey.org/methodology/ess_methodology/source_questionnaire/ http://www.europeansocialsurvey.org/docs/round7/questionnaire/ESS7_ source_main_questionnaire_final_alert_o3.pdf. http://ess.tk.mta.hu/adatbazis/ adatbazisok/. [Accessed 15 November 2016].

8. Füzér, K., 2015. A bizalom társadalomelmélete és a társadalmi tőke szociológiaelmélete. Századvég, 78(4), pp.5-18.

9. Grootaert, C. and Bastelaer, T., 2001. Understanding and measuring social capital. [online], Available at: http://siteresources.worldbank.org/INTSOCIALCAPITAL/ Resources/Social-Capital-Initiative-Working-Paper-Series/SCI-WPS-24.pdf. [Accessed 15 November 2016].

10. Jóna, G., 2013. A területi tőke fogalmi megközelítései. Tér és Társadalom, 27(1), pp.30-51.

11. Kabai, G., 2014. A balatoni társadalom kohéziójának kérdései. Területi Statisztika, 54(4), pp.376-393.

12. KSH (Central Statistical Office of Hungary), 2016. A Balaton idegenforgalmi régió vendégforgalma, 2015. [online], Available at: www.ksh.hu. [Accessed 20 July 2017].

13. LEADER European Observatory (LEADER EO), 1999. Territorial competitiveness. Creating a territorial development strategy in light of the LEADER" + experience. Part 1. LEADER European Observatory "Rural Innovation", Dossier no. 6. Brussels: LEADER EO.

14. Megyesi, B., 2015. A társadalmi tőke negatív hatásai. Századvég, 78(4), pp.107-128.

15. OECD, 2001. Territorial Outlook, Paris: OECD Publications Service.

16. Oláh, M., 2007. A megtalált régió, Comitatus, 17(3), pp.3-18.

17. Oláh, M., 2010. A területi identitás szerepe az igazgatási terek tervezésében. Területi Statisztika, 5o(4), pp.308-334. 
Review of Economic Studies and Research Virgil Madgearu, 2017, 10(2)

18. Palkó, K., 2010. Az identitás területi dimenziói a politika tükrében, Doktori Értekezés. Pécs: Pécsi Tudományegyetem.

19. Pálné, K.I. (ed.), 2009. A politika új színtere a régió, Pécs-Budapest: Századvég.

20. Putnam, R.D., 2000. Bowling alone. The collapse and revival of American community. New York: Simon and Schuster.

21. Schleicher, V., 2010. A Balaton-parti települések identitáskeresése a turizmus szolgálatában. Comitatus, 20(194), pp.22-35.

22. Szabó, I.L., 2014. Az intézményi, szervezeti bizalom helyzete Magyarországon 2014 elején. Nemzet és Biztonság, 3, pp.119-142.

23. Tóth, B., 2013. A területi tőke szerepe a regionális és városfejlődésben. Doktori Értekezés. Sopron: Nyugat-magyarországi Egyetem. 